\title{
The 1974 Outlook for Food and Agriculture
}

\author{
CLIFTON B. LUTTRELL and NEL A, STEVENS
}

HE U.S. Department of Agriculture has forecast a further increase in food prices in the first half of 1974 , followed by rising farm production and relatively stable food prices in the second half of the year ${ }^{1}$ Farm commodity and food prices rose sharply last year, reflecting, in part, a number of short-run supply and demand forces. In response, farmers are expected to increase production this year. Both crop and livestock product prices are expected to average somewhat above the 1973 level. However, in contrast to the rising prices during 1973, farm commodity prices are forecast to decline in the second half of this year. With rising farm production during the year, domestic food supplies per capita should rebound from the 1973 level which was 2 percent less than a year earlier and the lowest in four years.

This article provides both an analysis of national food and agriculture developments over the past two years and a general outlook for food and agriculture. Also included is outlook information for major crops and livestock products of the Central Mississippi Valley.

\section{FOOD}

Per capita food supplies in 1974 are expected to recover from most of their 1973 decline. Further increases in food prices have occurred this winter, but the average price of food at home is expected to stabilize about mid-year.

Rising production is expected to result in per capita consumption gains in livestock-related foods of about 1.5 percent for 1974 . Per capita red meat production is expected to rise about 3 percent from last year's relatively low level and poultry supplies should also be up following a 2 percent decline last year. Per capita egg production may increase somewhat. Dairy production will probably be down for the second consecutive year, but dairy imports are rising, hence the per capita consumption of dairy products will likely

\footnotetext{
The forecasts eited throughout this article are a summary of the U.S. Department of Agriculture reports given at the 1974 National Agricultural Outlook Conference held in Washington, D.C., in December 1973 and reports of subsequent months.
}

be up. Per capita supplies of crop foods for domestic consumption are expected to be about the same as a year ago.

While retail food prices are up in the first quarter of this year as a restlt of both declining farm output and rising marketing margins, they are expected to level off later in the year as increased farm ouput and declining farm product prices will tend to offset rising marketing costs.

\section{Food Otutpre Down Last Year}

Reflecting a number of short-run factors, per capita food supplies last year declined from the 1972 level. The decline was led by a 7 percent reduction in meat output which was only partially offset by a small gain in crop-related foods. This was the largest year-to-year decline in meat supplies in a quarter of a century. Per capita red meat available for domestic consumption was down about 14 pounds from 189 pounds in 1972. Most of the decline reflected reduced beef and pork supplies; however, veal, lamb, and mutton were also down somewhat.

Total production of livestock products in 1973 was down about 5 percent from the previous year. Domestic production, however, was augmented slightly by increased imports which accounted for 4.6 percent of livestock food supplies in 1973. Imports of dairy products rose sharply, accounting for 2 percent of domestic use.

Crop production last year was up about 5 percent, but most of the gain was in feed crops which were harvested in the late summer and fall, and had litte impact on the 1973 domestic food supply. Crop exports were up as a result of rising world demand and reduced world supplies, and imports, consisting largely of sugar and a number of tropical products, were down slightly. Consequently, domestic use of crop foods did not rise enough to offset the decline in livestockrelated food.

\section{Prices Sharyly Higher in $10 \% 3$}

The decline in food output last year in the face of a strong demand resulted in a sharp run-up in prices. 
Led by a rapid increase in meat prices, the price index of food in grocery stores rose 16 percent from 1972 to 1973 (see accompanying chart). Average food prices rose 23 percent from August 1972 to its peak in August 1973-more than during the entire period from 1967 to mid-1972. Meat, poultry, and fish prices rose 41 percent during this 12 -month period. Food prices declined somewhat in September and October, but turned up again later in the year.

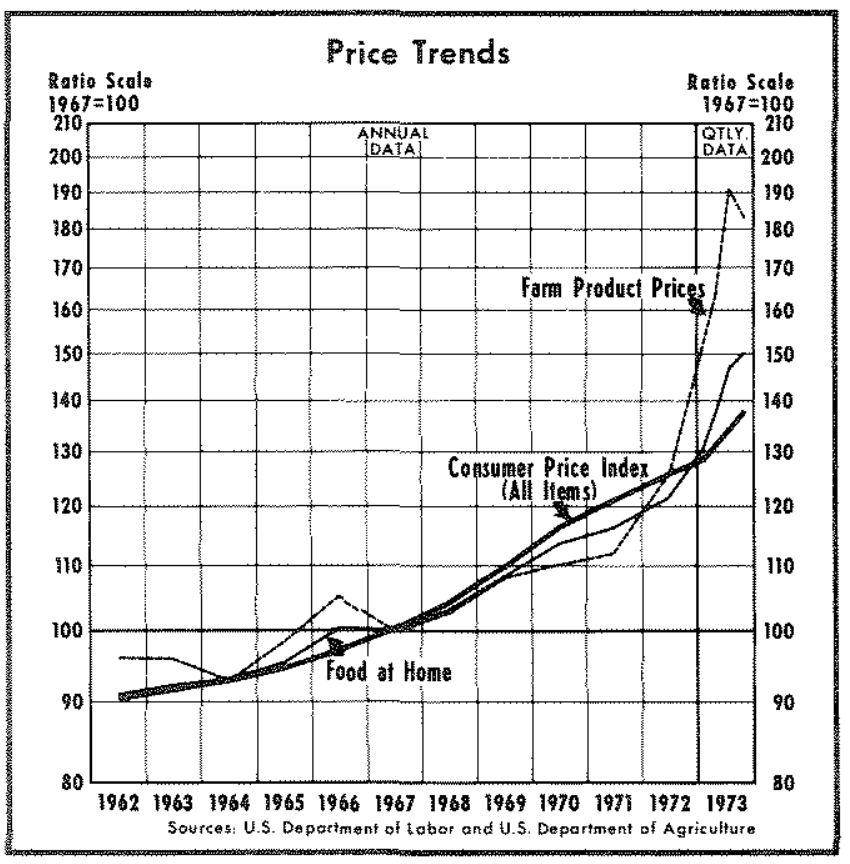

Until the recent upsurge, food prices have increased at a slower rate than other consumer prices since the acceleration of the inflation in the mid 1960s. From 1965 until 1972, the price index for food at home rose at an annual rate of 3.5 percent, while the index for all consumer items rose at an annual rate of 4.1 percent.

Reflecting the rising demand and reduced supply of food, all farm product prices last year averaged 37 percent higher than in 1972. Crop prices were up 43 percent and livestock prices rose 33 percent. Much of the increase in crop prices was the result of an increase in derived demand for, and reduced supplies of, livestock feed prior to harvesting last year. Feed demand derived through demand for livestock products continued to rise reflecting rising personal incomes both here and abroad. World supplies, however, were down as a result of relatively poor crops in 1972. Livestock feed prices rose 84 percent from $\mathrm{Au}$ gust 1972 to August 1973, and for the calendar year 1973 they averaged 52 percent higher than a year earlier. Hence, the short-run supply of livestock prod. ucts was reduced as feeding became more expensive; that is, a smaller quantity would be offered by producers at any given price level.

\section{Reduced Output and Higher Prices Caused by Short - Run Forces}

While some of the increase in food prices last year reflected the expansion of aggregate demand for all goods and services, much of the rise can be traced to a series of short-run supply and demand factors in the food industry. Price-wage controls in some cases, particularly the freeze on meat prices last summer, prevented part of the rising demand signals from reaching the producers, thus delaying increases in production. Sales of wheat and feed grain to the Russians in mid-1972 served to reduce domestic stocks and increase prices. The sharp decline in production of Peruvian fish meal led to a shortfall in world protein supplies and an unanticipated increase in export demand for soybean meal. Unfavorable crop harvesting weather in the United States in the fall of 1972 reduced crop output from expected levels. A decline in world crop production in 1972 and a realignment of world currencies led to an unexpected increase in export demand for U.S. crops. In addition, the sharp price increases for livestock tended to increase the numbers of animals going into domestic breeding herds and reduce the number placed in feedlots for slaughter.

\section{Food Output and Prices Adjusting to Longer. Run Forces}

These short-run fluctuations in food prices and output are self-correcting in a free market economy. Given sufficient time farmers can adjust their capital, labor, land, and other inputs so as to increase production. Hence, in the long run farm production is more responsive to price changes than in the short run. The higher prices for livestock feed and other crops in early 1973 provided incentive for an upswing in crop production last year. ${ }^{2}$ Total crop output jumped about 5 percent from the 1972 level or well above the average annual rate of 2 percent during the previous ten years. Acres planted to feed grains, wheat, rice, and soybeans rose $5,8,20$, and 22 percent, respectively.

With larger feed crops, livestock production began to expand in the fourth quarter of last year. Red meat production was forecast at 9 billion pounds in the fourth quarter, up from 7.9 billion in the third

\footnotetext{
2Less restrictive Govermment planting controls were also a factor in the larger feed crop output.
} 


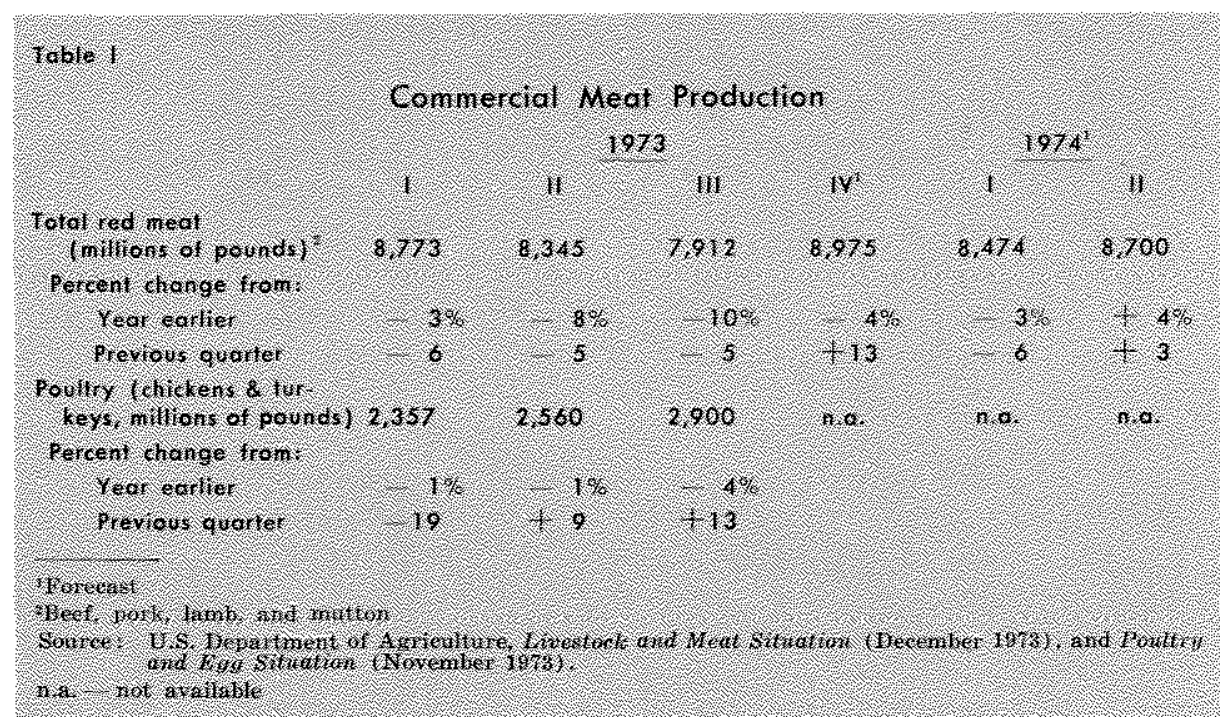

adjusts following a short-run disturbance. Producers quickly respond with additional output when prices rise and major opportunities for profit occur. Increased production, in turn, leads to a downward adjustment in prices. Some of that downward adjustment in food prices to more normal supply and demand conditions may occur this year.

If a high rate of inflation continues, most of the food price adjustment may occur through a decline in relative food prices rather than an actual price decline. Reflecting both short-run factors in the food industry and excessive demand, the general price level (measured by the GNP price defiator) has risen at an annual rate of 4.6 percent since early 1971 and the rate has accelerated in recent quarters. From fourth quarter 1972 to fourth quarter 1973, prices rose 7.3 percent, but most of the price acceleration during this period reflected rising food costs. Thus the relatively stable food prices forecast for late this year would contribute to a slower rate of inflation, and with continuing or accelerating inflation in prospect for other items, stable food prices should result in a resumption of the long-run downtrend in food costs relative to disposable personal income.

\section{Share of Personal Income Spent on Food Unchanged}

Although expenditures for food increased sharply last year, disposable personal income rose at a similarly high rate, resulting in little change in the portion spent on food. Food expenditures absorbed 15.8 percent of the total, only a fraction of a percent more than in 1971 and 1972 (Table II). Cost of food used at home was 12.3 percent of disposable personal in come, the same as a year earlier, and slightly less than in 1971.

While the share of disposable personal income spent on food has not declined in recent years, it may still be lower in the United States than in any other major industrial nation (Table III). In 1970 U.S. consumers spent only 13.4 percent of national income on food, beverage, and tobacco, the smallest percentage reported for these items by any major industrial nation of the Organization for Economic Cooperation and
3U.S. Department of Agriculture, Crop Production (January $22,1974)$. 


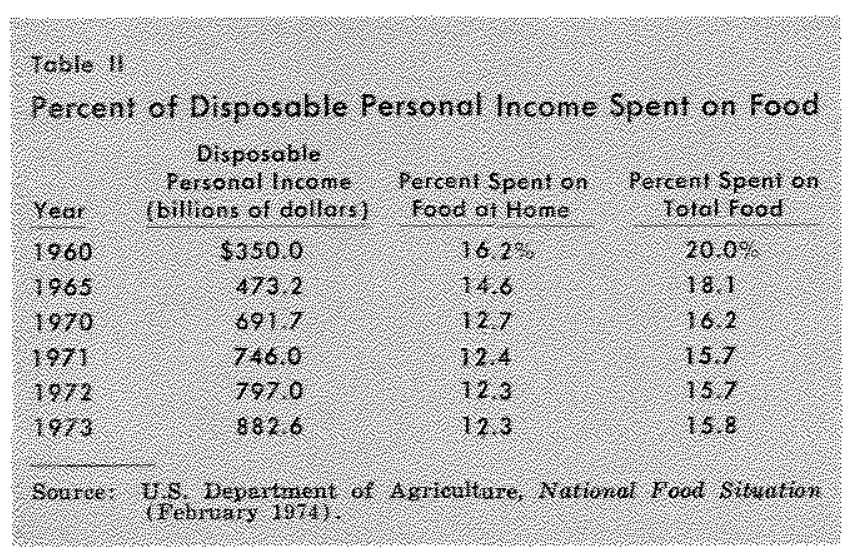

Development (OECD). A number of countries, including Canada, Japan, France, and Germany, made rapid progress in reducing food costs during the decade ending in 1970. However, it is still unlikely that any of them, except possibly Canada, can claim equal ity with the small share of disposable personal income spent on food in the United States.

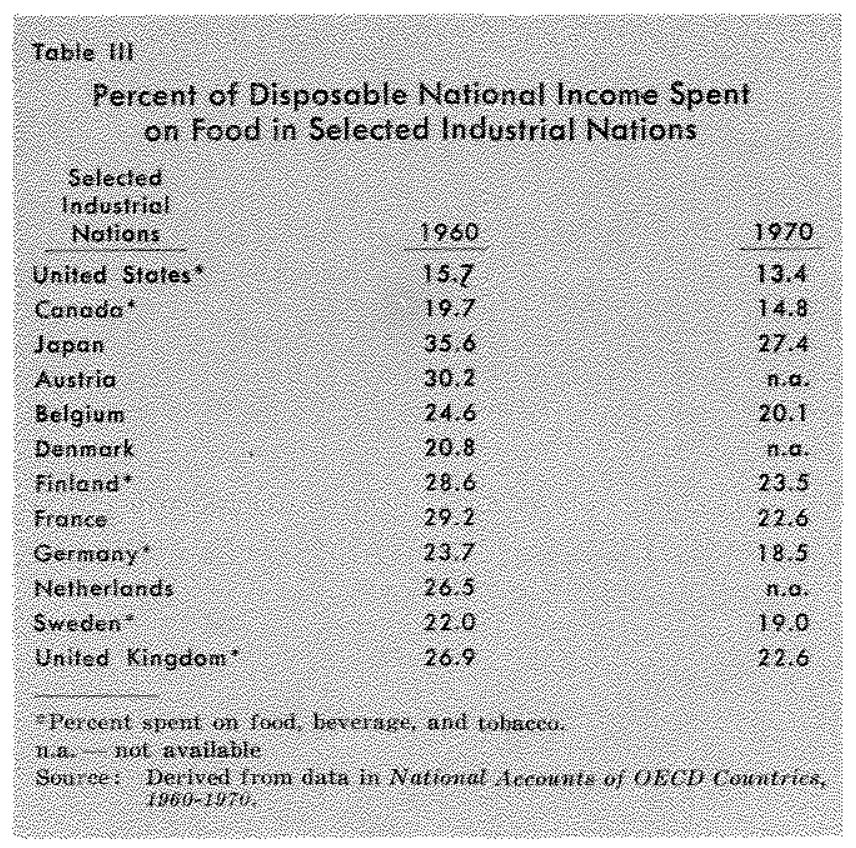

\section{AGRTCULTURE}

Realized net farm income is expected to total about $\$ 24$ to $\$ 25$ billion in 1974 , a decline from the record $\$ 26.1$ billion estimated for 1973 (see accompanying chart). Gash receipts from farm product sales are likely to be higher, reffecting a larger volume of production and higher average prices; direct Government payments to farmers, however, will probably be down sharply from the $\$ 2.6$ billion last year, and farm production expenses will rise. Nevertheless, the forecasted net farm income is still well above the amount realized in any year except 1973.
The decline forecast for realized farm income this year is based largely on rising farm production expenses. Resources for production are being bid up throughont the economy and farmers are facing sharply rising prices for most farm supplies. As a rem sult of both the higher prices and a larger volume of resources used, farm production expenses are expected to be well above the estimated $\$ 64.4$ billion last year.

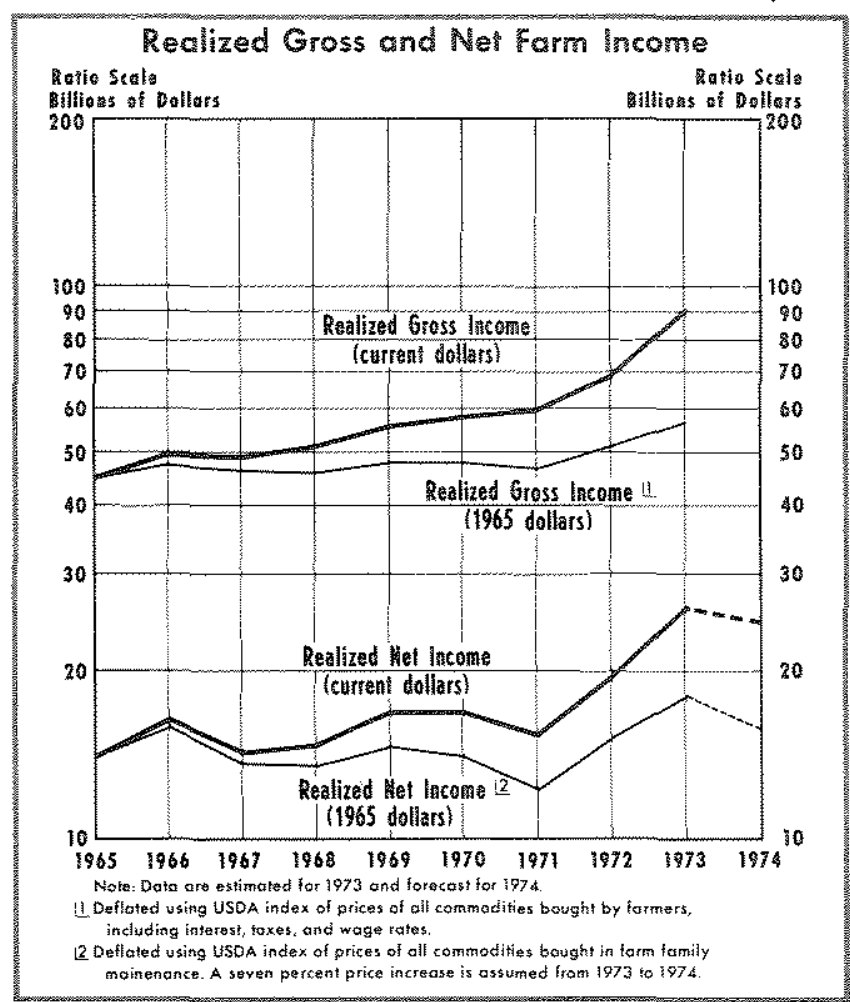

Although the forecasted net farm income for 1974 is relatively high when measured in current dollars, it is only about 18 percent more real income than the average received during the period 1965-72 inclusive. Deflated by the 1965 price index of commodities purchased for farm family living, the average realized net income was $\$ 14.1$ billion per year for the 1965-72 period, compared with the forecasted net for 1974 of $\$ 15.8$ billion (midpoint of forecast). Real income per farm, however, has increased somewhat faster as a result of the downtrend in the number of farms. Such income from farming averaged $\$ 4,613$ in 1965-72, an estimated $\$ 6,329$ last year, and is forecasted at $\$ 5,601$ for this year.

\section{Factors Afecting Fath Product Supply}

The supply of farm products for 1974 will tend to be reduced as a result of the sharply rising prices for productive resources. As indicated earlier, inflation has accelerated in recent quarters as a result of generally rising demand and a number of short-run factors 
affecting the food industry; a high rate of general inflation is forecast for 1974. This rising demand for final product has been translated into demand for resources as producers bid for their use. In addition, the problem is further exacerbated this year by the oil embargo of the Middle-Eastern nations which will tend to reduce the supply of farm resources. Resources such as labor, fuel, and capital used for the production of most goods and services are also important farm resources. Hence, prices that farmers must pay for many resources are determined by supply and demand conditions in all sectors of the economy.

The index of prices paid by farmers for all items used in production, including interest, taxes, and wages, was advancing sharply late last year. In December the index was 17 percent above a year earlier, and a continued uptrend in prices is anticipated this year for a number of major items, including fuel, labor, fertilizer, and some other chemicals.

Fertilizer, which accounts for about 5 percent of total farm production expenses, is likely to rise in price by about one-third from the 1972 average. The higher price reflects both reduced supply and higher demand. Rising production costs and price-wage controls have tended to reduce fertilizer production, while rising prices for farm products plus the lifting of Government controls on farm production have increased fertilizer demand.

Until 1973 fertilizer prices had been relatively stable for several years as a result of large increases in manufacturing capacity, especially nitrogen, in the late 1960s. Returns on investments had been depressed, tending to discourage investment in new capacity, at the time the pricewage controls were established in 1971. As output approached capacity levels in 1972, the controlled fertilizer price was not sufficient to provide incentive for new investments. The higher prices following removal of the controls will no doubt result in plant expansion. There is a lag, however, between the decision to invest in fertilizer facilities and increased fertilizer output; thus, the current year's fertilizer supply will not be enhanced greatly even with the higher prices.

In addition to abetting the capacity problem, the controls served to intensify the domestic fertilizer shortage last fall by providing greater incentive for producing firms to export their product than to sell to domestic farmers. World fertilizer prices had risen 30-35 percent above the Government controlled domestic prices. Many farmers were thus unable to obtain the desired amount of fertilizer for fall planted grain which will mean lower wheat production than would have otherwise occurred. Since the price controls were removed, American famers can bid for fertilizer on the same basis as farmers in other countries.

Further exacerbating the fertilizer supply problem is the rising cost of natural gas, a major raw material for making ammonia. North America still has major reserves of "sour" natural gas which can be used, although the processing of such gas is more expensive than other gas. Also, naphtha, fuel oil, and synthetic natural gas are higher priced substitutes for natural gas. In addition to the rising cost of raw materials for domestic fertilizer manufacturing, which tends to retard output, the Middle-Eastern countries are building nitrogen fertilizer plants based on their vast reserves of low cost "sweet" gas. Such competition will tend to inhibit further investment in domestic nitrogen plants, but will alleviate the world fertilizer supply problem.

Higher energy prices will also increase the cost of power for agricultural production. In 1972 farm fuel costs accounted for about 4 percent of total farm production expenses and about 3 percent of total gasoline and diesel fuel sales. However, farm purchases accounted for 17 and 22 percent, respectively, of liquid petroleum and propane gas sold. Prices paid by farmers for motor supplies, largely fuel, were 12 percent higher in mid-February than in mid-November and 26 percent higher than a year earlier.

In the allocation of energy, the Administrator of the Federal Energy Office has given top priority to agriculture. He reported that agriculture would be supplied with 100 percent of its "needs" for gasoline, propane, butane, and residual fuel oil. "Needs," however, tend to vary with price; that is, quantity demanded tends to decline as the price rises and to increase as the price declines. Agriculture would be in a more favorable position than the rest of the economy with respect to energy only if rationing or some form of a multiple price system is maintained. Otherwise the farm use of fuel will be determined by supply and demand conditions in a free market, and the fuel will be allocated according to the price that users are willing to pay.

One factor tending to offset the impact of rising input prices on farm product supply is reduced Government controls. Under the Agriculture and Consumer Protection Act of 1973, farmers have acquired more freedom to produce. Base acreage allotments have been maintained on which a guaranteed price will be paid. The guaranteed price, however, 


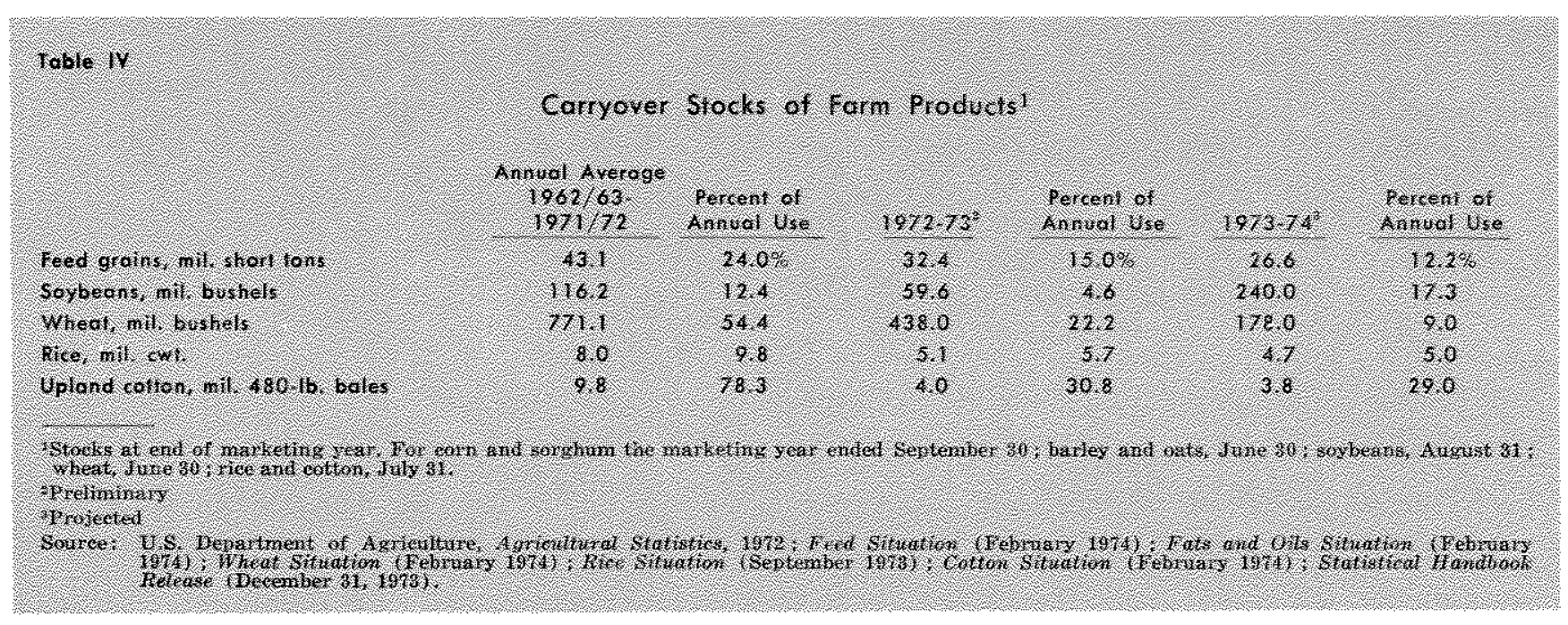

generally has been set well below the current market price, greatly reducing the taxpayer burden, and program eligibility does not generally require a reduction in crops such as a conserving base or set-aside acreage. With the more liberal planting provisions and the higher price incentive last year, the number of harvested acres rose sharply, increasing 10 percent to 312 million, and the forecast is for another increase of 10 million acres this year.

\section{Factors Affecting Farm Product and Food Demand}

Domestic food demand is expected to contimue up in 1974. Demand for food tends to rise with population and personal income growth. Population grew only about 0.8 percent from third quarter 1972 to third quarter 1973. However, personal income conm tinued sharply upward, rising 10.3 percent from 1972 to 1973 ; another sizable gain is forecast for 1974. Rising domestic demand for farm products is thus in prospect.

Demand for farm products for export and for inventory buildup may also be up this year. Exports of farm products are forecast to total $\$ 19$ billion in the marketing year 1973-74 - almost 50 percent above the previous record of last year. Most of the expected increase this year stems from higher prices as little change in volume of exports is anticipated. Exports jumped 60 percent to a record value of $\$ 12.9$ billion in fiscal 1973. Increased volume (mainly grain and grain products) accounted for more than half of the gain, and prices accounted for the remainder.

The expected increase in inventory demand is based on the relatively low level of carryover stocks for most major crops last year and the sharp increase in prices near the end of the marketing year. The carryover of soybeans was only 4.6 percent of annual use, just slightly more than the average quantity crushed during a two-week period. In contrast, the average carryover of soybeans from 1963 to 1972 was 12.4 percent of annual use (Table IV). Carryover stocks of rice, wheat, feed grains, and cotton in 1973 were also well below the 1963-72 average and are expected to remain relatively low in 1974 .

During the past two decades, the Government has held sizable quantities of farm commodity inventories at the taxpayer's expense - a method of inventory holding with which the private sector could not compete. Now that the Government has liquidated most such inventories, there will be greater incentive for private investors to participate in price-stabilizing operations through inventory holding. While private inventory holdings will no doubt average less than Govemment holdings during the last two decades, they will probably exceed the relatively small inventories carried over last year since most inventory holders realized sizable profits in 1973 .

\section{OUTLOOK FOR MAJOR FARM PRODUCTS OF THE CENTRAL MISSISSIPPI VALLEY}

\section{Feed Grains}

Total feed grain supplies for the nation in the current marketing year ${ }^{4}$ are estimated at 237.8 million tons, or 4 percent less than a year ago. The $1973 \mathrm{crop}$ was somewhat larger than a year earlier, but carryover stocks last year were down. Domestic use of feed

4Year beginning July 1,1973 for barley and oats and October 1,1973 for com and sorghum. 
grain in the current marketing year is expected to be down slightly from a year ago ( 171 vs. 173 million tons), reflecting reduced feeding last fall and some decline in the volume of exports. Stocks at the close of the year are forecast at 27 million tons, down 18 percent from a year earlier. Production in 1974 is projected at 235 million tons, 13 percent more than in 1973.

Feed grain prices in the first half of 1974 are expected to average well above the level of a year ago. Reduced supplies will tend to keep prices high until about mid-year. As the larger Southern Hemisphere crops move into world markets this spring, and as our own crops approach maturity in the summer, prices are likely to trend downward, and by next fall they may average below carrent levels.

\section{Wheat}

Wheat supplies for the current marketing year ending June 30, 1974, are estimated at 2,150 million bushels, down 11 percent from the 2,409 million bushels of a year ago. Production of 1,711 million bushels in 1973 was up about 10 percent from a year earlier, but last year's carryover of 438 million bushels was only about 50 percent of the year-earlier level and 40 percent of the $1963-72$ average.

The forecast of wheat usage in the current year of 1,972 million bushels is the same as in 1972-73. Closing inventories may be down 50 percent or more from the relatively low carryover last year. Domestic use of wheat may be down to about 772 million bushels this year from 787 million a year ago, largely reflecting a reduction in the use of wheat for livestock feed. Exports are expected to total 1,200 million bushels, up about 1 percent from a year ago and about double the average annual commercial exports for the decade 1962-1972. Larger wheat supplies are in prospect for 1974-75. Total production may exceed 2 billion bushels which, coupled with some decline in exports, would result in a sizable increase in carryover stocks next year.

\section{Rice}

Despite some increase in production last fall, rice will remain in relatively short supply this year. Carryover last July 31 was down to 5.1 million cwt, less than half the 1965-71 average; carryover this year is forecast at 4.7 million cwt, the lowest since 1952 . Rice production last year totaled 92.8 million cwt, up 9 percent from a year earlier. Exports this year are projected at 55.4 million cwt., shightly above last year's level, and domestic use for food and brewing is expected to continue upward. Total use is projected at 93.7 million cwt, slightly in excess of production last year.

The mid-August 1973 farm price of $\$ 10.70$ per cwt. for rice was almost double that of a year earlier. For the marketing year ending July 31, 1974, the price is expected to average about double the loan rate of $\$ 6.07$ per cwt. The national rice acreage allotment was reduced for 1974, but marketing quotas were lifted and there are no controls on the acreage that can be planted.

\section{Soybeans}

Soybean production in 1973 rose 23 percent in re sponse to higher prices, yet supplies remain relatively "tight" and the average price of $\$ 5.50$ per bushel during the harvest season was more than double that of a year earlier. The total supply of 1,626 million bushels this year is a record high, 21 percent above the supply last year. Usage is expected to increase about 100 million bushels, but with last year's higher production, carryover on August 31 may rise to 240 million bushels, up from 60 million last year. Both domestic crush ings and exports are expected to rise somewhat, but not sufficiently to prevent a sharp buildup of stocks.

In contrast to the sharp increase in the price of soybeans to more than $\$ 10$ per bushel following harvesting in 1972, soybean prices may be at a peak this winter. Nevertheless, prices during the 1973-74 marketing year are expected to average about $\$ 5.65$ per bushel. The lower soybean-com price ratio this year is likely to cause farmers to shift from soybeans to corn since the two crops are often competitors for the same land. Hence, acreage planted to soybeans may be down from the 57 million acres a year ago.

\section{Cotton}

The supply of upland cotton, totaling 17 million bales, is sfightly above the 16.8 million bales of a year ago, reflecting somewhat larger beginning stocks. As a result of excessive rainfall and floods in the Mississippi delta areas, production in 1973 was down to 13 million bales from 13.6 million a year earlier. Mill consumption is expected to decline to 7.4 million bales from 7.7 million a year ago, but exports may rise to 5.7 million bales from 5.3 million. Total cotton usage, domestic plus exports, is estimated at 13.1 million bales, which would be slightly above that of 1972-73. Carryover stocks at the close of the current year are forecast to be down slightly from the 4 million bales last year. 
The guaranteed target price for the 1974 cotton crop is 38 cents per pound, while the current market price of 60-65 cents per pound is more than double that of a year ago. Given this price incentive and no set-aside or conserving base requirement, larger plantings are anticipated. Forecasts indicate an 18 percent acreage increase.

\section{Tobacco}

The tobacco crop was a little larger last year than in 1972, but tobacoo consumption is up and carryover stocks at the end of the year are expected to decline. The supply of both flue-cured and burley tobacco is down somewhat from the 1972-73 level and usage of both has been slowly increasing.

Sizable amounts of tobacco still remain under Govermment loans, and Government price supports for the crop are mandatory. The support price, which usually determines the price to farmers, will go up 8 to 9 percent for the 1974 crop. Furthermore, the national marketing quota may be increased for burley tobacco.

\section{Bes Conle}

The 1974 forecast for fed beef cattle is for somewhat higher prices and a smaller volume of marketing in the first quarter followed by a rising volume of marketings and declining prices about mid-year. This outlook is based largely on the cattle inventory which has moved upward since 1967 and accelerated in recent years. On January 1,1974 , there were $127.5 \mathrm{mil}-$ lion cattle and calves on farms, 5 percent more than a year earlier. With a 5 percent larger beef calf crop, and a 7 percent increase in steers weighing 500 pounds and over, inventory growth of feeder cattle has increased from the relatively high rate of inventory growth in 1973.

Despite the rising inventory of feeder cattle, the number on feed in 23 major feeding states on January 1 was 6 percent less than a year earlier. There was 55 percent more cattle than a year earlier in the 1,100 pound-and-over weight group and 11 percent more in the 900 to 1,099 pound group. However, there were fewer cattle than a year ago in the lighter weight groups, and fed cattle marketings this winter are expected to be down slightly from last winter.

Larger numbers of heavier animals are expected to be placed on feed in early 1974. These feeders will reach market weight more quickly than usual, resulting in larger beef supplies by summer. Some increase is also forecast for cow slaughter this year.

\section{IIogs}

Hog slaughter in the first half of 1974 is forecast to lag year-ago levels. However, this winter, with the high price incentive and the larger feed supplies, farmers are expected to increase their brood sows and their March-May farrowings. This should result in some increased slaughter next fall.

Hog prices will be heavily influenced by beef supplies and prices. Consequently, the smaller winter production forecast for beef and pork should result in higher hog prices, but they may not rise seasonally in the spring if beef supplies increase as anticipated. With rising supplies of both pork and beef in the second half of the year, pork prices will likely decline.

A recent U.S. Department of Agriculture report on hogs and pigs indicates a higher rate of slaughter in the first half of 1974 than was anticipated at the December Outlook sessions. This report shows that for every weight group the number of market hogs and pigs on farms as of December 1, 1973, was greater than a year earlier. If the higher rate of slaughter is achieved, hog prices this winter and spring could be lower than was anticipated in the earlier outlook reports.

\section{Poibtry and Lggs}

Poultry and egg production is expected to be up in 1974 after lagging year-earlier levels in 1973. Broiler production is expected to expand moderately and turkey production is projected to run well ahead of the year-ago levels. Egg production is expected to expand very rapidly in the early spring as a result of a 14 percent increase in the number of pullets available for flock replacement.

Weekly broiler chick placements for December 1973 marketing were up slightly from a year earlier, and the placements for early 1974 marketing were down about 4 percent. However, the hatchery supply flock is growing and may exceed the 1973 flock by spring. This larger broiler supply base, coupled with higher red meat prices in prospect for this winter, is expected to encourage broiler output since broilers are a substitute for red meat. Turkey poults for marketing in early 1974 were 13 percent above the year-ago level. Turkey eggs in incubators, from which the poults will be hatched for marketing in the second half of 1974 , were 8 percent more on November 1 than a year earlier.

Both broiler and turkey prices are forecast to increase during the early months of this year, but then 
lag 1973 prices in the remaining months. Egg prices are expected to decline seasonally this winter and spring and to be less than year-earlier levels by mid-year.

\section{Darry Products}

Milk production is expected to decline slightly again this year following a 3 percent reduction last year. Production, estimated at 116.8 billion pounds for 1973 , was about the same as two decades ago. The number of milk cows and heifers on farms has declined almost 50 percent since 1950 , but rising production per cow prior to last year about offset the reduction in cow numbers. Cow numbers continued down last year, but for the first time in almost 30 years production per cow declined, reflecting unfavorable milk-feed price relationships.

Most of the decline in milk production this year is expected to occur by mid-year. The milk-feed price ratio should improve during the year and provide greater incentive for feeding and production in the second half of the year. Dairy supplies have in recent years been augmented by rising imports, which accounted for about 2 percent of domestic consumption last year.

Farm milk prices last year averaged about $\$ 1$ per hundred pounds over the 1972 level of $\$ 6.07$. In the first quarter of 1974 , milk prices continued to show strong gains over year-earlier levels; however, they may tend to stabilize after mid-year.

\section{SUMMAR}

The nation's farmers in 1974 are expected to increase their output and receive somewhat higher average prices for their products than a year ago. Farm production costs will rise sharply, however, and direct Government payments to farmers will be down.
Hence, net farm income will likely decline from the record $\$ 26.1$ billion estimated for last year.

Food output and prices are adjusting to longer-term trends following a decline in output and sharply higher prices last year. Food output this year is expected to recover from most of the 1973 decline. However, most of the gain will come in the second half of the year.

Food prices are up again in the first quarter of the year, but with rising farm output later in the year, they are expected to stabilize. Declining farm commodity prices will then tend to offset rising food processing and marketing costs.

While food costs may appear to be high to most consumers, such costs as a percent of disposable personal income have remained relatively stable since 1972. The cost of food used at home has remained at 12.3 percent of disposable personal income for two years and is down from 16.2 percent in 1960.

Rising prices for resources used in farm production are tending to shift the supply schedule for farm products to the left; that is, reduce output at any given price level. Reflecting rising general demand for resources, and in some cases reduced supplies, major price increases are in prospect for a number of critical farm inputs such as labor, fertilizer, and fuel. Government crop production controls, however, are being eased which tends to inorease the supply of farm products and to offset the output effects of the higher priced farm resources.

Demand for farm products continues to rise at a rapid rate, reflecting a small increase in population and large increases in personal income and export demand. Thus, despite the supply response this year to the sharply higher food prices, only moderate downward adjustments in farm commodity prices are likely after the mid-year peak.

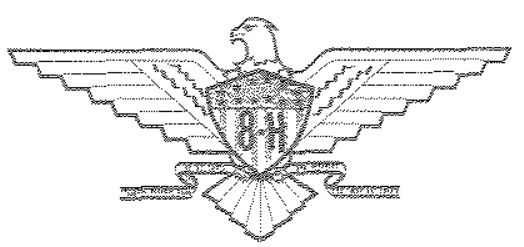

